\title{
VOLUMETRIC AND CYTOLOGIC VARIATION IN THE PINEAL BODY OF PEROMYSCUS LEUCOPUS (RODENTIA) WITH RESPECT TO SEX, CAPTIVITY AND DAY-LENGTH ${ }^{1}$
}

\author{
W. B. QUAY \\ Department of Anatomy, Eniversity of Michigan \\ Medical School, Ann Arbor \\ THIRTEEN FIGURES \\ INTRODUCTION
}

The functional significance of the mammalian pineal organ has remained obscure, in spite of the efforts of many investigators. Nevertheless, in recent years increasing evidence suggests that the pineal has an antigonadal or antigonadotrophic activity (Simonnet, Thieblot, Melik and Segal, '54; Kitay and Altschule, '54; and others). Since the pineal of certain lower vertebrates is a light receptive organ, and since reproduction in some vertebrates including mammals is affected by day-length, the significance of the pineal in regard to photoperiodic responses should be examined.

The white-footed mouse (Peromyscus leucopus), a feral, nocturnal, polyestrous species with an annual winter anestrum, has been shown to be affected in its reproductive activity by changes in day-length (Whitaker, '40). Whitaker found that in light of varying daily duration according to an annual schedule the anestrum occurred in the short day-season, and that blinded mice did not exhibit cyclic reproductive activity. Due to the availability of the white-footed mouse and the knowledge of its photoperiodic reproductive behavior, this

\footnotetext{
${ }^{1}$ Financial support for publication was provided by funds derived from income on the endowment of the Horace H. Rackham Sehool of Graduate Studies, University of Michigan.
} 
species was chosen for the present investigation. It is believed that cytological data presented here on the pineal in relation to modifications of day-length may provide evidence on the mechanism of photoperiodic behavior as well as on pineal function.

I am grateful to Dr. Wayne L. Whitaker for helpful information and the use of certain apparatus.

MATERIAL AND METHODS

Thirty-two adult white-footed mice (Peromyscus leucopus) obtained from the same woodland tract in Washtenaw County, Michigan, were used in this study. Throughout their period of captivity the mice were kept in separate cages. The bottoms of the cages, solid and covered with wood shavings and shredded paper, measured $10 \times 15$ inches; the height of the cages was 8 inches. Cages exposed to artificial light in the laboratory were constructed entirely of wire mesh, except for the bottom. Food and tap water were available to the animals at all times. The food consisted of Dice's ('34) Peromyscus ration without wheat germ, hemp seed, millet seed, and iodized salt. Lettuce and apple slices were supplied once a week. Artificial illumination of the animals was supplied by ordinary household 60-100 watt electric light bulbs delivering a measured 40-100 foot-candles to the closest portions of the interiors of the cages. Within each cage there was sufficient bedding so that the mice could be in nearly complete darkness when they desired. The artificial illumination of the animals was controlled by an automatic timer and consisted of a single period of light per day timed to occur near the middle of the natural day. While in the laboratory, the mice were at a temperature of $19^{\circ}-26^{\circ} \mathrm{C}$. Although the mice at no time came into contact with each other, the mice within each experimental group could hear and see the animals in neighboring cages.

The experimental mice have been arranged into 7 groups according to their month of capture and the nature of their 
subsequent treatment. The description of these experimental groups is summarized in table 1. For all mice except no. 32 the date of capture refers to the date of capture in the outdoor habitat. All subsequent treatment, except the first treatment period for no. 1, were in the laboratory. Animals given 14-18 hours of light per day were given a day-length which gradually increased from 14 to 18 hours during the first two

TABLE 1

Treatment and history of experimental animals

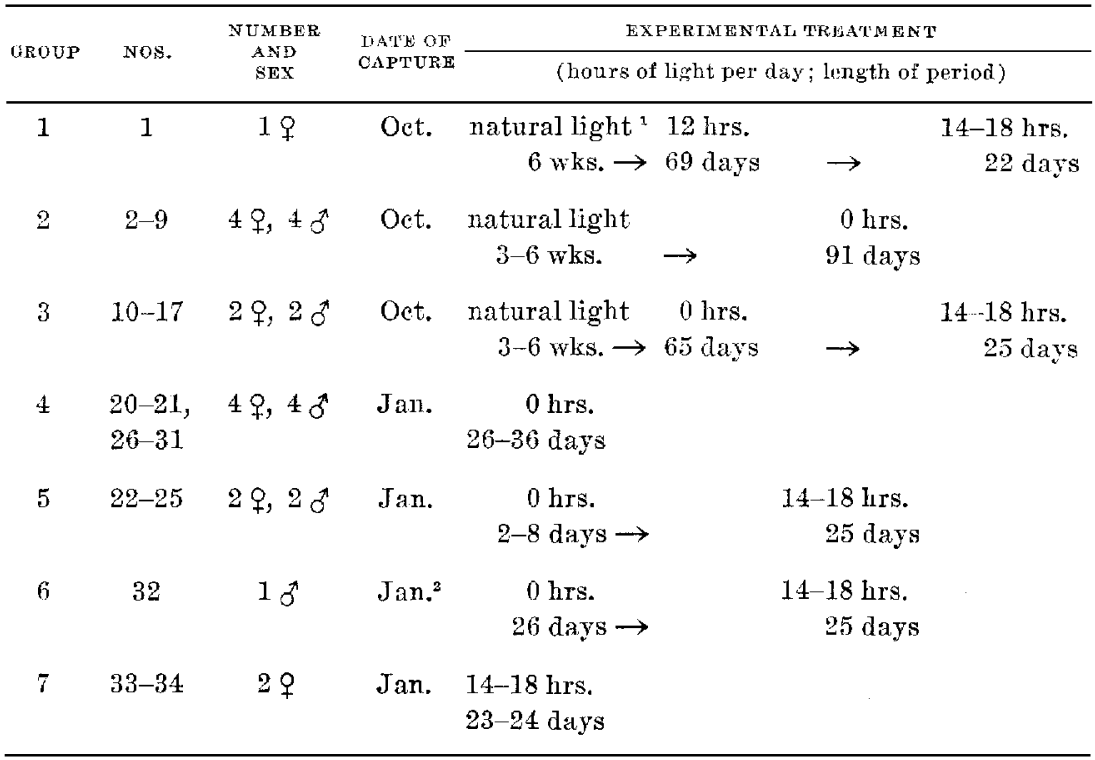

${ }^{1}$ Outdoors 6 weeks.

- Captured in laboratory.

weeks and which was maintained at 18 hours for the remainder of the experiment.

The mice were sacrificed by means of ether anesthesia to death. Anesthesia of all mice was performed between 2:00 and 5:30 P.M., and with minimal disturbance by placing each caged mouse into a large covered can containing ether. The mice were not handled until unconscious. They were then weighed, measured and perfused via the heart with Bouin's 
fluid $\left(75 \mathrm{~cm}^{3}\right.$ sat. aq. pieric acid, $25 \mathrm{~cm}^{3}$ formalin, $5 \mathrm{~cm}^{3} \mathrm{gl}$. acetic acid). Sixteen hours later each brain with attached hypophysis, pineal and meninges was removed and placed in Bouin's fluid for approximately two days. The central area of each brain with attached hypophysis and pineal was then washed in several changes of $70 \%$ ethanol, dehydrated, cleared and embedded in paraffin. Serial cross sections $7 \mu$ in thickness were affixed in order to glass slides, 10 sections per slide. Alternate slides were stained with chrome hematoxylin and phloxine (Gomori, '41) and paraldehyde-fuchsin with Orange G, Light Green SF, and chromatrope 2R (Halmi, '52). The hematoxylin portion of the latter technique was omitted.

\section{RESLITS}

The anatomy of the pineal body. The pineal body of Peromyscus leucopus consists fundamentally of two parts. The more anterior and basal of these surrounds a dorsal evagination of the third ventricle (fig. 1) and is closely associated basally with the subcommissural organ and the habenular commissure. The more posterior and dorsal part of the pineal lies near the surface, between the cerebral hemispheres and over the anterior part of the cerebellum. Between the two parts of the pineal there is a continuous strand of pineal tissue in $31 \%$ of the animals, an interrupted strand of pineal tissue in $44 \%$, scattered islets of pineal tissue in $22 \%$, and no intermediate pineal tissue in $3 \%$. There is no correlation between sex and abundance or arrangement of intermediate pineal tissue.

The anterior pineal is characterized by closely spaced cells with little circumnuclear cytoplasm and many phloxinophilic fibers. The posterior pineal is characterized by less closely spaced cells with more circumnuclear cytoplasm and few phloxinophilic fibers. Since the tissue of the connecting strand or islets resembles that of the posterior part of the pineal more closely than that of the anterior part of the pineal, the intermediate strands or islets are classed with the posterior pineal proper. The junction between the anterior and pos- 
terior pineal types of tissue always occurs close to the anterior pineal mass. The intermediate strand of posterior pineal tissue sometimes overlaps the posterior part of the anterior pineal and, although in contact with it, can be histologically distinguished from it. However, the junction of the two types of pineal tissue is sometimes indefinite and for convenience the boundary is placed at the center of the first marked constriction at the posterior tip of the anterior pincal.

From the foregoing description it can be concluded that complete pinealectomy or complete posterior pinealectomy would be difficult in this species. This is in contrast with the laboratory rat (Rattus) in which there is little pincal tissue near the basal attachment next to the third ventricle.

Volumetric variation. The volumes of the anterior and posterior pineals were computed from outline camera lucida drawings of every fifth section in the following manner. The area of each outline drawing was determined by planimetry. The area of the sections between the drawn and measured ones were arithmetically graded between the values obtained for the measured sections. The areas of parts of the pineal were obtained by: (1) adding the computed areas of the drawn sections and those lying between drawn sections, (2) multiplying by the thickness of the section and (3) dividing by the square of the magnification of the drawn sections. There are numerous sources of error possible with this method of determining volume, but these possible errors appeared to be slight and insufficient to affect greatly the variation of the resulting figures. The magnitude of the probable errors in the volumes varied greatly from specimen to specimen. Errors due to: tissue compression during sectioning, optical distortion, variation in drawing technique, variation in planimetry, and variation in the areas of the sections between the sections which were actually measured were found to be slight. Of greater concern were errors due to variation in section thickness and creation of abnormal spaces by excessive perfusion pressure. Errors due to occasional sections of different thickness were detected by their difference in 
staining and were corrected by comparing the cell content with that of adjacent sections of normal $(7 \mu)$ thickness. Evidences of perfusion artifact were seen in only a few specimens, and were slight in extent. They were not calculated or corrected. However, computation of the content of cells in the pineal removes the possible error due to perfusion artifact. Calculations were made of the number of cells in the pineal, including neuroglial and parenchymal cells but excluding connective tissue cells (fibroblasts, mast cells, phagocytes, lymphoid cells), cells associated with blood vessels (endothelial cells and smooth muscle), ependymal cells and subcommissural organ-type cells. For counting the number of cells in the pineal a cover glass with a square etched on one surface was placed at a suitable level in the ocular of the microscope. The area of this square, in terms of the tissue section being observed through it, was determined with a stage micrometer and planimetry of a camera lucida outline drawing of the circumscribed area. By counting the number of pineal nuclei lying within this square a computation could be made of the number of cells in this known area, since binucleate or multinucleate pineal cells were believed to be absent or extremely rare. Cell counts were made in this way in every 10th section of the posterior pineal at measured intervals varying in magnitude according to the size of the section. Generally over a hundred cells (nuclei) were counted in each such section. In very small sections, all of the cells were counted. In the anterior pineal, cell counts were made in the same way but only in the section at or very near the posterior tip of the pineal recess of the third ventricle. In the posterior pineal the cell density is usually much greater proximally and peripherally. This necessitates the making' of cell counts at definite intervals and in sections at all levels.

The pineal volumes and cell contents of the specimens are presented in table 2. It should be noted first that there is great individual variation in these figures. When the data are grouped and compared in terms of sex, length of time in captivity, and exposure to darkness or increased day-length, 
TABISE 2

Folumes of the anterior (Ant.) and posterior (Post.) parts of the pineal organ in $\mathrm{mm}^{3}$ and in estimated cell content. $\bar{x}=$ mean. Se =- standard error of the mean. $C=$ coefficient of variation. $\bar{x}_{\delta}==$ mean of males. $\bar{x}_{+}=$mean of females.

\begin{tabular}{|c|c|c|c|c|c|c|c|c|c|}
\hline \multirow{2}{*}{\multicolumn{2}{|c|}{$\begin{array}{l}\text { SPECMMEN } \\
\text { NUMBER } \\
\text { A.ND SEX }\end{array}$}} & \multirow{3}{*}{$\begin{array}{c}\text { HEAD } \\
\text { AND } \\
\text { RODY } \\
\text { LENGTH } \\
m m\end{array}$} & \multirow{3}{*}{$\begin{array}{l}\text { TOTAL } \\
\text { BODY } \\
\text { WGT. } \\
g m\end{array}$} & \multicolumn{3}{|c|}{ PPNEAL VOLUME } & \multicolumn{3}{|c|}{ PINEAT, OELL CONTENT } \\
\hline & & & & \multirow{2}{*}{\multicolumn{2}{|c|}{$\begin{array}{ll}\text { Ant. } & \text { Post. } \\
& m m^{3}\end{array}$}} & \multirow{2}{*}{ Sum } & \multirow{2}{*}{\multicolumn{2}{|c|}{$\begin{array}{l}\text { Ant. Post. } \\
\times 1 / 1000\end{array}$}} & \multirow{2}{*}{ Sun } \\
\hline & & & & & & & & & \\
\hline 1 & P & 98 & 19.4 & .0200 & .1617 & .1817 & 256 & 982 & 1238 \\
\hline 2 & q & 91 & 16.2 & .0170 & .0896 & .1072 & 284 & 500 & 784 \\
\hline 3 & $q$ & 97 & 30.3 & .0202 & .0740 & .0942 & 302 & 445 & 747 \\
\hline 4 & $q$ & 99 & 27.0 & .0246 & .1316 & .1562 & 297 & 836 & 1133 \\
\hline 5 & $q$ & 93 & 17.9 & .0208 & .1588 & .1796 & 309 & 942 & 1251 \\
\hline 6 & 0 & 92 & 24.6 & .0223 & .0789 & .1012 & 322 & 524 & 846 \\
\hline 7 & $\delta$ & 99 & 30.0 & .0169 & .0570 & .0739 & 248 & 477 & 725 \\
\hline 8 & $\sigma$ & 93 & 26.5 & .0144 & .0396 & .0540 & 233 & 424 & 657 \\
\hline 9 & 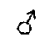 & 90 & 18.6 & .0220 & .1379 & .1599 & 286 & 1067 & 1353 \\
\hline 10 & $q$ & 94 & 21.3 & .0130 & .0657 & .0787 & 270 & 1048 & 1318 \\
\hline 11 & $\delta$ & 93 & 18.7 & .0180 & .0342 & $.0 \tilde{0} 22$ & 313 & 420 & 733 \\
\hline 12 & 0 & 95 & 28.1 & .0129 & .0477 & .0606 & 228 & $\ldots$ & $\ldots$ \\
\hline 13 & $d$ & 95 & 23.9 & .0210 & .0936 & .1146 & 245 & 668 & 913 \\
\hline 14 & $\delta$ & 97 & 30.3 & .0171 & .0840 & .1011 & $\ldots$ & $\ldots$ & $\cdots$ \\
\hline 15 & $\delta$ & 93 & 26.2 & .0257 & .0917 & $.117 t$ & 246 & 611 & 857 \\
\hline 16 & q & 92 & 18.3 & .0251 & .0825 & .1076 & 308 & 766 & 1074 \\
\hline 17 & $d$ & 92 & 21.4 & .0210 & & & 233 & $\ldots$ & $\ldots$ \\
\hline 20 & $\delta$ & 92 & 26.9 & .0267 & .1210 & .1477 & 171 & 899 & 1070 \\
\hline 21 & $\delta$ & 95 & 28.3 & .0139 & .0755 & .0894 & 209 & 912 & 1121 \\
\hline 22 & 9 & 90 & 21.9 & .0217 & .1330 & .1547 & 525 & 1318 & 1843 \\
\hline 23 & $q$ & 93 & 22.1 & .0223 & .0996 & .1219 & 305 & 790 & 1095 \\
\hline 24 & $\delta$ & 90 & 26.3 & .0199 & .0623 & .0829 & 198 & 602 & 800 \\
\hline 25 & $d$ & 92 & 26.0 & .0232 & .1716 & .1948 & 373 & 1325 & 1698 \\
\hline 26 & $q$ & 86 & 18.2 & .0193 & .0957 & .1150 & 270 & 1048 & 3318 \\
\hline 27 & 9 & 97 & 24.7 & .0208 & .1175 & .1383 & 303 & 1009 & 1312 \\
\hline 28 & $q$ & 86 & 19.4 & .0197 & .0801 & .0998 & 351 & 804 & 1155 \\
\hline 29 & 욤. & 85 & 19.7 & .0188 & .0720 & .0908 & 264 & 618 & 882 \\
\hline 30 & $\delta^{n}$ & 90 & 27.5 & .0188 & .0510 & .0698 & 253 & 509 & 762 \\
\hline 31 & $\sigma^{\pi}$ & 97 & 33.7 & .0169 & .0618 & .0787 & 232 & 551 & 783 \\
\hline 32 & $\delta$ & 90 & 19.3 & .0155 & .0543 & .0698 & 205 & 388 & 593 \\
\hline 33 & 9 & 93 & 22.6 & .0250 & .1120 & .1370 & 200 & 684 & 884 \\
\hline 34 & $q$ & 89 & 19.7 & .0163 & .0340 & .0503 & 213 & 337 & 550 \\
\hline $\bar{x}$ & & 93 & 23.6 & .0197 & .0894 & .1090 & 273 & 742 & 1017 \\
\hline Se & & & & .0021 & .0068 & .0072 & 11.97 & 51.08 & 58.12 \\
\hline $\mathrm{C}$ & & & & .5907 & .4209 & .3669 & .2444 & .3710 & .3077 \\
\hline$\vec{x}_{0}^{\pi}$ & & 93 & 25.7 & .0192 & .0789 & .0980 & 250 & 670 & 922 \\
\hline $\mathrm{x} q$ & & 92 & 21.2 & .0203 & .1005 & .1209 & 297 & 808 & 1106 \\
\hline
\end{tabular}


it is found that there is a sexual difference but no differences correlated with captivity or day-length. As the mean values in table 2 indicate, the average volume and cell content of the female pineal, particularly the posterior part, exceeds those averages of the male. However, the ranges of the figures for the two sexes broadly overlap and the amount of individual variation reduces further the probable significance of this sexual difference.

Cytologic variation. Cytologic variation was examined in pineal cells in three categories: (1) anterior pineal cells (excluding stromal, ependymal, and subcommissural-type cells), (2) posterior pineal cells, and (3) chrome hematoxylin positive cells. In addition, the phloxinophilic processes and fibers in the anterior pineal, and the aldehyde fuchsin-staining material in both parts of the pineal were studied.

The staining techniques which were used in this study, failed to demonstrate the cytoplasmic contents in the great majority of pineal cells and the outlines of the cells were often obscure. However, the volume of the pineal cells showed marked individual variation. Since the boundaries of many of the cells were vague, an indirect method of estimating average pineal cell volume was used. From the data on the volume and cell content of the pineal, computations were made of the number of pineal cells per $\mathrm{mm}^{3}$. Since the pineal stroma and intercellular spaces appeared to be minimal and of approximately the same relative volume in the animals, pineal cell density per $\mathrm{mm}^{3}$ was used as an index of mean pineal cell volume. The figures for number of pineal cells per $\mathrm{mm}^{3}$ were computed for the anterior pineal in the section at or near the tip of the pineal recess of the third ventricle. The figures for the number of pineal cells per $\mathrm{mm}^{3}$. were computed for the posterior pineal from data on all sections in which cell counts and pineal areas were measured. Analysis of the resulting figures for pincal cells per $\mathrm{mm}^{3}$ failed to reveal any significant correlation with sex, length of captivity, or day-length treatment. But the difference between anterior and posterior pineals in cell density was found to be significant 
(table 3). There also appeared to be some, if perhaps slight, positive correlation between cell densities in anterior and posterior pineal of the same animals.

Visible cytologic variations, other than cell volume, were limited to nuclear structures in most of the pincal cells. A study of nuclear structural variation was made in both anterior and posterior pineal cells to ascertain whether sub-

TABLE 3

Comparative cytology of the anterior and posterior parts of the pineal. Cells $\times$ $10^{5}$ per $\mathrm{mm}^{3}=$ number of pineal (parcnchymal + neuroglial) cells per oubie millineter. Xuclear cliameter $=$ mean melear diameter of pineal cells $(50$ nuclei were measured in each part of the pineal in each specimen). Wianeter largest granule $=$ mean diameter of largest phloxine-staining nuclear granule per pineal cell fin 50 nuclei in each part of the pineal in each spccimen). Total granale volume=mean total volume per nucleus of phloxine-staining gronules of s5 $\mu$ diameter or larger (in so nuelei in each part of the pineal in each specimen). Se = standard error of the mean. Range $=$ obstrved range. $N=$ number of animals.

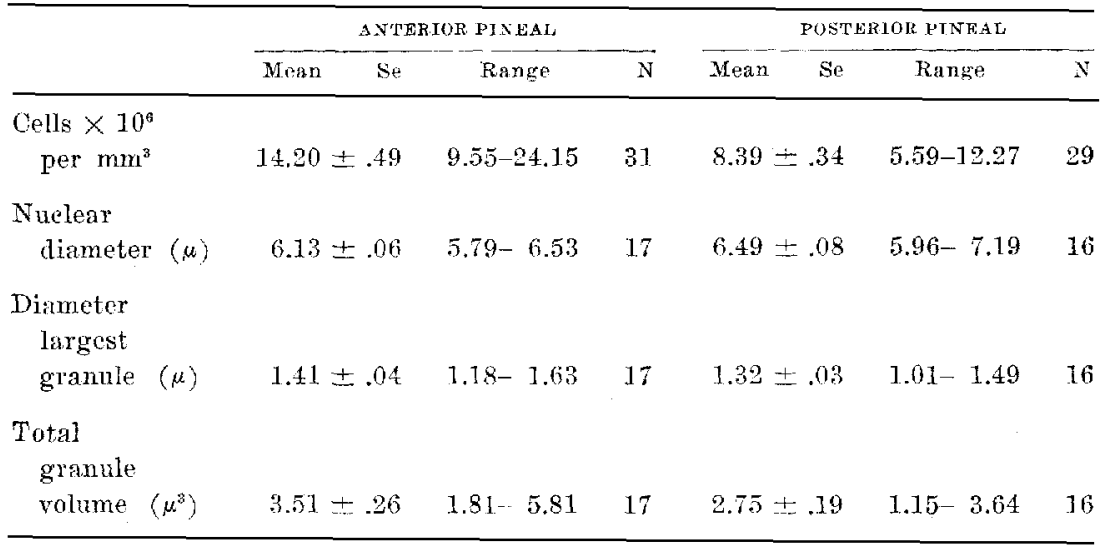

types of cells might be distinguished by means of nuclear morphology and whether certain structural variations might be correlated with sex, length of captivity or modification of day-length. Sections stained with chrome hematoxylin and phloxine were found to be most suitable for studies of nuclear morphology and were therefore used for this purpose. Nuclear morphology of anterior pineal cells was studied in one section at or near the tip of the pineal recess of the third ventricle and 
nuclear morphology of posterior pineal cells was studied in a section at or near the part of the posterior pineal of greatest cross-sectional area of each animal. In each section, camera lucida drawings were made of fifty nuclei whose maximum dimensions were in the optical plane at mid-depth in the section and which were thus as nearly entirely within the section as posible. The nuclei were drawn from small areas defined by a reticle and of an equal distance from each other and covering the entire sectional area of the pineal. The outline of each nucleus was drawn from the optical plane revealing the maximal nuclear dimensions. And within each nucleus the phloxine-staining granules were drawn, each from the optical plane revealing the maximal true dimensions.

The outline drawings of pineal nuclei and their phloxinophilic granules were analyzed first for half of the animals to determine which nuclear characteristics might be bi-or polymodal and which offered possibly significant correlations with sex or history of the animals. From the nuclear drawings, measurements were made of maximum and minimum nuclear diameters, mean diameter of all phloxinophilic granules equal to or over $.55 \mu$ in mean diameter, and the number of these phloxinophilic granules equal to or greater than $.55 \mu$ in mean diameter per nucleus. From these figures, were computed mean nuclear diameters and the total volumes per nucleus of the phloxinophilic granules. Frequency diagrams of these characteristics in several animals with extreme or mean values demonstrated no significant bi-or polymodality, but they did show marked individual variation in the ranges, variances and means. The data were then analyzed to determine whether cytologic correlations with sex, length of captivity or modification of day-length were evident. The mean nuclear diameter and the mean diameter of the largest phloxinophilic granule per nucleus in anterior and posterior pineal cells showed no such correlations. But there was evidence of correlations between increased day-length and lower mean number of phloxine-staining granules $(=$ or $>.55 \mu$ mean diameter) per nucleus and lower total volume of these granules per nucleus 
in both anterior and posterior pineals. Calculation of the total volumes of the granules was extremely laborious and the results were so variable that it appeared unlikely that calculation of granule volumes for the remaining animals would contribute much to the significance of possible correlations. The mean number of phloxine-staining granules in pineal cells was determined for all animals which could be used in comparisons of the effects of darkness and increased day-length of the pineal (table 4). The difference between the mean number of these nuclear granules in animals in the two groups was found to reach a statistical significance at least in the posterior part of the pineal.

\section{TABLE 4}

Comparison of the mean number of phloxine-staining granules $=$ or $>.55 \mu$ in mean diameter) per pineal cell in anterior and posterior pincals, in animals in darkness in comparison with those in 14-18 hours of light per day. Animals in groups 1 and 6 (table 1) were omitted, since their history or treatment differed. $S e=$ standard error of the mean. $R=$ observed range. $N=$ number of animals.

\begin{tabular}{|c|c|c|c|c|c|c|c|c|}
\hline & \multicolumn{4}{|c|}{ ANTERIOR PINEAL } & \multicolumn{4}{|c|}{ POSTERIOR PINEAL } \\
\hline & Mean & $\mathrm{Se}$ & Range & $\mathrm{N}$ & Mean & $\mathrm{Se}$ & Range & $N$ \\
\hline Darkness & 5.26 & $=.33$ & $2.62-7.06$ & 16 & 5.26 & .22 & $3.48-7.54$ & 16 \\
\hline Light & 4,40 & $=.40$ & $2.74-8.28$ & 13 & 4.16 & .26 & $2.82-6.08$ & 12 \\
\hline
\end{tabular}

* Student-Fisher $t$ test, significance of differences between means.

Ten to ninety per cent of the pineal cell nuclei are deeply incised or lobed, in the posterior part of the pineal. Differential counts of incised and not incised nuclei in the cross-sections of greatest area in each posterior pineal for half of the animals failed to reveal any significant correlation with sex, captivity or day-length.

Cells containing cytoplasmic granules staining black with chrome hematoxylin were discovered in the anterior pineal and anterior part of the posterior pincal in most animals (figs. 2, 3 and 6). These cells could not be distinguished from pineal parenchymal cells by their nuclear morpholgy. Thus their detection and enumeration had to be based upon the 
presence of cytoplasmic granules. The number of granules within each cell varied from few to so many that the cells appeared completely filled by them. The cytoplasmic granules frequently could be traced out into long cytoplasmic processes leading usually posterior-ward into adjacent areas of pineal tissue. In slides stained with aldehyde fuchsin, few of the cytoplasmic granules of these cells were stained (fig. 5). In cells with many cytoplasmic granules usually at least some of the granules were stained dark blue by the aldehyde fuchsin. The characteristics of these cells which distinguish them from other granular cells in the pineal should be pointed out (see plate 2). Subcommissural organ cells, mast cells, and phagocytes are the only other heavily granular cell-types that occurred in the pineal stained by the techniques used here and which might be confused with the specific cell type described above. In the basal part of the anterior pineal and often distant from both the ependymal layer and the subcommissural organ, cells identical with subcommissural organ colls were sometimes seen (figs. 11, 12). These differed from the above described "granule cells" chiefly in having (1) a smaller nucleus containing more small granules, thus appearing more ependyma-like, and (2) cytoplasmic granules smaller in size and staining less intensely with chrome hematoxylin. The staining of subeommissural organ cells in the rat with the two techniques used here has been described by Wislocki and Tueduc ('54).

Mast colls are common in the periphery of the pineal and are sometimes present in the interior of either the anterior or posterior parts of the organ. Mast cells differed from the above-described "granule cells" chiefly in having: (1) a smaller nucleus containing more large granules, and (2) cytoplasmic granules of larger size and less intense staining reaction with chrome hematoxylin (figs. 8, 9, and 10).

In the pineal connective tissue, phagocytes were seen in a few specimens. The cytoplasmic inclusions of these cells 
were variable in size and appearance, and did not stain intensely with chrome hematoxylin (fig. 7).

Between the pineal cells variable amounts of aldehydefuchsin staining material were seen in most specimens, especially in the posterior pineal. This material is in the form of a delicate intercellular network along which are distributed irregular masses of material (figs. 4 and 13). The fine fibers of the network cannot be distinguished from elastic fibers, which stain similarly with aldehyde fuchsin. But the irregular masses of material definitely associated with the fine fibers, are not readily attributed to elastic fibers or other stromal products. And they usually are located between and in close contact with pineal parenchymal cells rather than in association with blood vessels or strands of connective tissue. Tho network is stained pale to dark gray by chrome hematoxylin, while the associated masses of material are stained to a lesser extent. The origin of the network and the associated irregular masses is unknown and direct continuity between this material and the "granule cells" was not observed. However, the fibrous cxtensions of the "granule cells" and the similarity of the staining reactions of their granules to the staining reactions of the intercellular network and masses, suggested a possible connection. The cytoplasmic extensions of the granule cells" extended primarily in a posterior direction and toward the part of the pineal where the intercellular material was most abundant. The fact that the granules of "granule cells" are more intensely stained with ehrome hematoxylin while the intercellular material stains more intensely with aldehyde fuchsin might be interpreted as indicating a progressive chemical change in material of the same origin. Quantitative appraisals of the relative amounts of intercellular aldehyde fuchsin-staining material and numbers of "granule cells" in the pineals were made (table 5 ). The resulting figures demonstrated a negative correlation $(\mathrm{r}=-.452)$ between the number of granulated "granule cells" and the amount of aldehyde 


\section{TABLE 5}

Comparison of relative amounts of aldehyde fuchsin-staining material and number of chrome hematoxylin-staining "granule cells", in the anterior and posterior pineals. Specimens nos. 6 and 14 were omittcd due to the fact that some critical sections were missing in one and staining was unsatisfactory in the other. The amount of aldehyde fuchsin-staining material in each part of the pineal was graded from o to +++ , likewise the extent of granulation of each granule cell was graded from + to +++ . The estimated total amount of aldehyde fuchsin-staining material was compated by doubling the number of $+s$ recarded for the posterior pineal and adding the number recorded for the anterior pineal. No. = specimen number (history of each is given in table 1).

\begin{tabular}{|c|c|c|c|c|c|c|c|c|c|c|c|c|}
\hline \multirow{3}{*}{ No. } & \multirow{2}{*}{\multicolumn{3}{|c|}{$\begin{array}{l}\text { AMOULT OF ALDE HYDE FUCHSIX- } \\
\text { STAINING MATERIAL }\end{array}$}} & \multicolumn{9}{|c|}{ NUMBER OF "GRANULE CELLS" } \\
\hline & & & & \multicolumn{4}{|c|}{ Posterior pineal } & \multicolumn{4}{|c|}{ Anterior pineal } & \multirow{2}{*}{ Total } \\
\hline & $\begin{array}{l}\text { Posterior } \\
\text { pineal }\end{array}$ & $\begin{array}{c}\text { Anterior } \\
\text { pineal }\end{array}$ & $\underset{\text { total }}{\text { Estimated }}$ & + & ++ & +++ & Total & t. & ++ & +++ & Total & \\
\hline 1 & + & + & 3 & 3 & 10 & 7 & 20 & I & & & 1 & 21 \\
\hline 2 & $+t+$ & $+t$ & 8 & & & 2 & 2 & & 3 & & 3 & 5 \\
\hline 3 & $+t$ & 0 & 4 & & & & 0 & 21 & 19 & $\underline{2}$ & 35 & 35 \\
\hline 4 & $+t$ & + & 5 & & & & 0 & 4 & 4 & & 8 & 8 \\
\hline 5 & $+t$ & ++ & 6 & 1 & & & 1 & 5 & 2 & 1 & 8 & 9 \\
\hline 7 & + & 0 & 2 & 2 & 18 & 31 & 51 & 30 & 41 & 4 & 75 & 126 \\
\hline 8 & $+t+$ & + & 7 & 2 & & & 2 & & & & 0 & 2 \\
\hline 9 & 0 & 0 & 0 & 1 & & & 1 & 1 & 21 & & 22 & 23 \\
\hline 10 & $t+$ & ++ & 6 & & & & 0 & & & & 0 & 0 \\
\hline 11 & $+t+$ & ++ & 8 & & & & 0 & & & & 0 & 0 \\
\hline 12 & 0 & 0 & 0 & 1 & & & 1 & & & & 0 & 1 \\
\hline 13 & $+1+$ & + & 7 & 2 & 4 & & 6 & 2 & & & 2 & 8 \\
\hline 15 & $+t$ & $+t$ & 6 & & & & 0 & 3 & 9 & 35 & 27 & 27 \\
\hline 16 & $+t$ & + & 5 & & 2 & & 2 & 5 & & & 5 & 7 \\
\hline 17 & ++ & 0 & 4 & & & & 0 & & & & 0 & 0 \\
\hline 20 & $+t+$ & $t$ & 7 & 9 & 7 & 36 & 52 & 32 & 8 & 1 & 41 & 93 \\
\hline 21 & + & 0 & 2 & 1 & & 13 & 14 & 2 & 8 & 49 & 59 & 73 \\
\hline 29 & + & 0 & 2 & 12 & 25 & 35 & 72 & 25 & 32 & & 57 & 129 \\
\hline 23 & 0 & + & 1. & 1 & & & 1 & 3 & 36 & 28 & $6 \pi$ & 68 \\
\hline 24 & ++ & $+t$ & 6 & & & & 0 & & & & 0 & 0 \\
\hline 25 & ++ & $+t$ & 6 & 1 & 1 & 1 & 3 & & & & 0 & 3 \\
\hline 26 & + & 0 & 2 & & 5 & 1 & 6 & 2 & 7 & 18 & 27 & 33 \\
\hline 27 & $+t+$ & + & 7 & 2 & 4 & 14 & 20 & 1 & & 2 & 3 & 23 \\
\hline 28 & 0 & 0 & 0 & 8 & 41 & 51 & 100 & 18 & 9 & & 27 & 127 \\
\hline 29 & + & + & 3 & 6 & 10 & 1 & 17 & 5 & 1 & & 6 & 23 \\
\hline 30 & $+t$ & + & 5 & & & & 0 & & & & 0 & 0 \\
\hline 31 & $+t$ & 0 & 4 & & & & 0 & & & & 0 & 0 \\
\hline 32 & +1 & + & 5 & & & 1 & 1 & 4 & 6 & & 10 & 11 \\
\hline 33 & + & + & 3 & 5 & 4 & & 9 & 3 & 2 & 2 & 7 & 16 \\
\hline 34 & + & + & 3 & & & & 0 & & 2 & & 2 & 2 \\
\hline
\end{tabular}


fuchsin-staining material in the pineals. This correlation coefficient lies between the $2 \%$ and $1 \%$ levels of significance. The hypothesis that the "granule cells" are responsible for the deposits of aldehyde fuchsin-staining material in the pineal might be supported by this negative correlation, since storage of granules in "granule cells" is shown to be concomitant with little intercellular aldehyde fuchsin-positive material and depletion of granules is concomitant with abundant intercellular material. In specimens in which few "granule cells" were observed (table 5) it is believed that many were undetected or nearly depleted of granules since frequently clusters of only a few granules could not be readily associated with any particular cell and were not counted.

Attempts to demonstrate relationships between either the number of granulated "granule cells" or the amount of intercellular aldehyde fuchsin-staining material with length of captivity, sex, day-length, body weight, weight to head and body length ratio, and cytology of pineal parenchymal cells, were unsuccessful.

There are numerous phloxinophilic neuroglial and neural fibers in the anterior pineals of all of the animals. Some of these fibers show variation in diameter and estimates of average fiber thickness were made for all animals. This fiber variation did not appear to be related to sex, treatment of the animals, or other measured variations in the pineal.

Masses of lymphoid cells of uncertain significance were associated with the pincals of a few animals and were not included in the volumetric or cytometric analyses.

Occasional neurons were seen in a couple of the pineals, but they were too few to yield data of significance. Neither pigment cells nor calcareous deposits were seen in any of the pineals.

\section{DISCUSSTON}

The results described above raise two problems which require further discussion: (1) the identification, relationships and significance of the "granule cells" and the aldehyde fuchsin-positive intercellular networks and deposits, and (2) 
the meaning of the cytological difference between pineals of animals in darkness and those in an increasing day-length.

In the human pineal del Rio Hortega ('29, '32), using the silver carbonate method found granular gliocytes of a similar structure, relative number, and distribution as the chrome hematoxylin-staining granule cells described here. He considered these to be secretory cells localized in the interstitial neuroglia. However, neither he nor other authors, apparently, have described intercellular deposits of material strictly comparable to those described here staining with aldehyde fuchsin. Typical reticular and clastic fibers are usually most prevailent near vessels and are not accompanied by irregular masses of similarly staining material. But the curled or twisted fibers ("Fibras ensortijadas") of Achúcarro and Sacristán ('12) (also described by del Río Hortega, '32; Amprino, '35; Bargmann, '43) are similar to parts of the intercellular network deseribed here.

Three circumstances described in the results above suggest a connection between the granules of the granule colls and at least part of the intercellular aldehyde fuchsin-positive material: (1) similar staining reactions, (2) posterior-ward trend of granule cell processes to areas of intercellular networks, and (3) inverse correlation between degree of granulation of the granule cells and amount of intercellular aldehyde fuchsin-staining material. An attractive hypothesis to explain these circumstances would be that the granular gliocytes are secreting material over their fibrous processes or that they are storing and then transporting this material to the immediate vicinity of the parenchymal cells. During passage the transported material gradually loses its granular character, becomes less readily stained with chrome alum hematoxylin and more intensely stained with aldehyde fuchsin. The secreted material might conceivably have a stimulative or nutritive function with regard to the pineal parenchymal cells. It may be significant, however, that neither the extent of gliocyte granulation nor the amount of the intercellular material appear to be correlated with cytological differences 
in the parenchymal cells. And it is conceivable that the granular gliocytes are phagocytic cells or that they serve to transport materials away from the parenchymal cells. However, the structure of the intercellular material, and that of the cytoplasmic granulation, are more typical of a secretory process than of an ingestive one. Preliminary experiments to test these ideas have been undertaken.

Pineal parenchymal cells have been shown to be engaged in an active nucleoprotein synthesis (Wislocki and Dempsey, '48) and investigators have long been concerned with nuclear secretory activity in the pineal (see Bargmann, '43). Certainly the amount of demonstrable nuclear material, or the number and size of the nucleoli, has a bearing on nuclear synthesis and activity. In the parenchymal cell nuclei of animals subjected to an increasing day-length there were fewer nuclear granules than in those of animals remaining in continuous darkness. This might be interpreted either as an indication of increased nuclear secretory activity or of reduced nuclear protein synthesis. On the basis of the cytology of other kinds of protein-producing cells (Caspersson, '50) the latter seems more likely. Therefore, it might be suggested that the larger number of nuelear granules in animals in continuous darkness indicates a greater rate of protein synthesis. This would be in line with the hypothesis that the pineal has an antigonadotrophic activity, since Whitaker ('40) found that white-footed mice kept in continuous darkness have a lowered as well as a non-cylic reproductive activity, and Fiske ('41) found that female rats kept in the dark experience prolonged periods of metoestrus, apparently because of a decline in FSH secretion.

Investigators concerned with the mechanism of increased gonadotrophic activity in warm-blooded animals exposed to increasing day-length have been faced with the question of how the gonadotrophin secreting cells of the anterior pituitary are stimulated (for a recent review see Amoroso and Matthews, 55). A nerve pathway from the optic system seems a likely clement in this mechanism. However, attempts to demonstrate 
significant direct innervation of the cells of the anterior pituitary have been equivocal or unsuccessful (Vázquez-López and Williams, '52; Green, '52; Harris, '52; Zuckerman, '52; and others) and neither the integrity of the visual cortex nor of the mid-brain is essential to the photoperiodic response in ferrets, although integrity of the optic nerve and retinal stimulation are necessary (Clark, McKeown, and Zuckerman, '39; Zuckerman, '52). The following evidence suggests the possibility of the pineal being an endocrine factor in the control of photoperiodic pituitary gonadotrophic activity: (1) the primitive pineal functions as a light receptive organ (Bargmann, '43), (2) recent evidence suggests that in mammals the pineal has an antigonadotrophic or antigonadal activity (Kitay and Altschule, '54), (3) nerve fibers from the habenular and posterior commissures end on the pinal parenchymal cells and these endings degenerate completely when these fibers are eut (Gardner, '53), (4) the major portion of the nerve fibers of the pineal gland derived from the habenular commissure probably arises mainly in the habenular nuclei (Gardner, '53), and (5) habenulo-tectal and habenulo-diencephalic interconnections exist or are probable in mammals (Kappers, Huber, and Crosby, '36). Further experimentation, however, is necessary before a decision can be reached on the role of the pineal in photoperiodic antigonadotrophic activity.

\section{SLMMARY}

Analysis of the volume and cytology of the pineal organ in thirty-two, adult, white-footed mice with respect to sex, length of time in captivity ( $3 \frac{3}{4}-4 \frac{1}{2}$ mos. versus $\frac{3}{4}-1$ mo.) and modification of day-length (darkness versus increasing daylength) by means of serial sections stained with chrome alum hematoxylin and phloxine or with aldehyde fuchsin demonstrates that:

1. The pineal in this species consists of an anterior and basal part around a recess of the third ventricle and a more 
posterior part lying between the cerebral hemispheres and over the anterior end of the cerebellum. Pineal tissue between these parts varies in amount from none to a complete interconnecting strand.

2. The volumes of the parts of the pineal are (means \pm standard errors) in $\mathrm{mm}^{3}$ and cell content (parenchyma + neuroglia): Anterior: $.0197 \pm .0021 \mathrm{~mm}^{3}, \quad 273,000 \pm 11,970$ cells; Posterior: $.0894 \pm .0068,742,000 \pm 51,080$.

3. The posterior pineal differs histologically from the anterior chiefly in that it has few phloxinophilic fibers and it has parenchymal cells of a greater size and mean nuclear diameter.

4. Large nuclear phloxine-staining granules in the parenchymal cells average more in number per nucleus in animals maintained in darkness in contrast with those in an increasing day. This may indicate a greater protein synthetic activity in the former, and possibly is concerned with the postulated antigonadotrophic activity of the pineal.

5. In the anterior pineal and in the basal part of the posterior pineal, granular cells staining intensely with chrome alum hematoxylin and less so with aldehyde fuchsin are described and are tentatively identified as granular gliocytes.

6. Heavily granulated cells of this type counted in alternate slides numbered from 0 to 129 (estimated total $=2 \times$ that, or $=-$ about 250 ) per pineal.

7. The number of heavily granulated cells of this type in the pineals is inversely proportional to the amount of a similarly staining intercellular material, which is most abundant in the posterior pineal.

8. This material is associated with the parenchymal cells and is in part morphologically distinct from typical elastic fibers or other previously described elements.

9. Significant volumetric or cytologic differences correlated with sex or length of time in captivity are not found.

10. Evidence suggesting the possibility that the pineal is a factor in photoperiodic gonadotrophic control is summarized. 


\section{IITERATURE CITHD}

ACHt́darRo, N., AND J. M. SACRIsTín 1912 Investigaciones histológicas y histopatológicas sobre la glándula pineal humana. Trab. Labor. invest. biol., Univ, Madrid, 10: 185-208.

Amoroso, F. C., AND L. H. MATrinws 1955 The effect of extemal stimuli on the breeding-eycle of birds and mammals. Brit. Med. Bull,, 11: $87-92$.

Anprino, R. 1935 Trasformazioni della ghiandola pineale dell'nomo e degli animali neld accrescimento e nella senescenza. Arch. Ital. Anat. e di Embriol., $94: 446-485$.

BaRgmaNe, W. 1943 Die Epiphysis cerebri. In: Mollendorff, W, von, Handb. mikr. Anat. Menschen, 6(4) : 309-502.

Caspersson, T. O. 1950 Cell growth and ecll function. W. W. Yorton and Co., New York.

Clark, W. E. Le Gros, T. MeKeown and S. Zugkerman 1939 Visual pathways coneerned in gonadal stimulation in ferrets. Proc. Roy. Soc. London (B), 196: 449-468.

Dicf, J. R. 1934 An improved Peromyscus ration. J. Mamm., 15: 160-161.

Fiske, V. M. 1941 Effect of light on sexual maturation, estrous cycles, and anterior pituitary of the rat. Endocrinol, 99: 187-196.

Garnner, J. H. 1953 Innervation of pineal gland in hooded rat. J. Comp. Neur., $99: 319-330$.

Gomori, G. 1941 Observations with differential stains on human islets of Langerhans. Am. J. Path., 17 : 395-406.

GRen, J. D. 1952 Comparative aspects of the hypophysis, especially of blood supply and innervation. Ciba Found. Collog. on Endocrinology, 4 : $79-86$.

HaImT, N. S. 1952 Differentiation of two types of basophils in the adenobypophysis of the rat and the mouse. Stain Technol., 27 : 61-64.

IARRIs, G. W. 1952 Hypothalamic eontrol of the anterior pituitary gland. Ciba Found. Colloq. on Endoerinology, f: 106-114.

Kappers, C. I. Ariëns, G. C. IIUBer 4 DD E. C. Crosbr 1936 The comparative anatomy of the nervous system of vertebrates, ineluding man. vol. 2, Macmillan Co., New York.

KiTAY, J. I., AND M. 1). ALTschur, 1954 The pineal gland. Harvari Thiv. Press, Cambridge, Mass.

net Río Hortera, P. 1929 Constitución histológiea de la glándula pineal. III. Actividad secretora de las células parenquimatosas y nenróglieas. Areh. de Neurobiol., 9: 139-167.

1932 Pineal gland. In: Penfield, W., Cytology and cellular pathology of the nervous system, vol. 2. Paul B. Hoeber, New York.

Simonnfi, H., L, Thieblot, T. Melik AND V. Segal, 1954 Nouvelles preuves de l'endoerinie epiphysaire. Aeta Fndoerin., $1 \%: 402-413$.

Vazquez-López, E., Ant P. C. Whimas 1925 Nerve fibers in the rat arenohypophysis unfer normal and experimental conditions. Ciba Found. Colloq. on Fndoerinologs, 4 : 54-64. 
Whitaker, W. L. 1940 some effects of artificial illumination on reproduction in the white-footed mouse, Peromyscus leucopus noveboracensis. J. Exp. Zool, $83: 33-60$.

WislockI, G. B., AND E. W. DENPSEY 1948 The ohemical histology and cytology of the pineal body and neurohypophysis. Endocrinology, $42: 56-72$.

Wislocki, G. B., AND E. H. LEDCC 1954 The eytology of the subeommissural organ, Reissner's fiber, periventricular glial cells and posterior collieular recess of the rat's brain. J. Comp. Neur., 101: $283-310$.

Zuckermav, S. 1952 The influence of environmental changes on the pituitary. Ciba Fourd. Colloq. on Fndocrinology, $t: 213-228$. 


\section{PLATE 1}

EXPLANATION OF FIGURES

1 Cross-section of the anterior pineal at mid-level. A reess of the third ventricle is enclosed by the anterior pineal and another ventricular recess lies dorsal to the anterior pineal. $\times 159$.

2 Large "granule cell," showing intensity of staining of the cytoplasmice granules. $\times 1860$.

3 Cross-section of strand of pineal tissue between the anterior pincal and the main mass of the posterior pineal. Four "granule cells" are shown. $\times 390$.

4 Small area in posterior pineal, showing large masses of aldehyde fuchsinstaining material. $\times 506$.

Figures 1,2 and 3 are from preparations stained with chrome alum hematoxylin and phloxine. Figure 4 is from a preparation stained with aldehyde fuchsin, orange G, light green SF, and chromotrope $2 R$. All figures are unretouched photographs. 

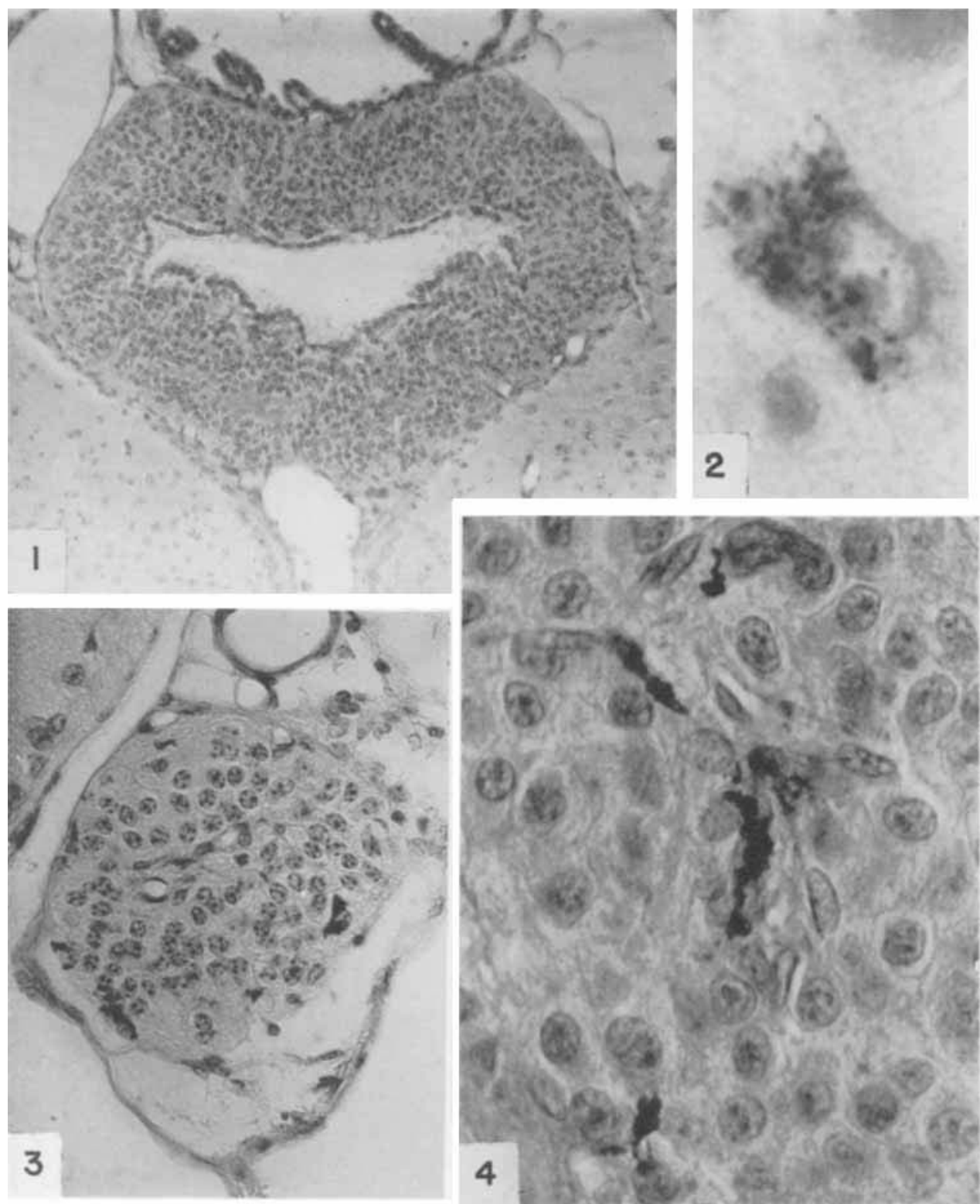


\section{PIIATE 2}

EXPLANATION OF FIGURES

5 Large "granule cell" from the anterior part of the posterior pineal. Note the incomplete staining of the eytoplasmic granules by aldehyde fuchsin.

6 "Granule cell" of arerage size and strueture. Note intense staining of nearly all granules by chrome ahum hematoxylin.

7 Pliagocyte from stroma of posterior pineal.

8 Mast cells with large eytoplasmie granules, from connective tissue near the pineal.

9 and 10 Mast cells representing extremes in nuclear size and number of cytoplasmic granules.

11. Isolated pair of subeomnissural organ-type cells in the anterior pineal.

12 Subcommissural organ-type cell from the posterior commissure adjacent to the ventral margin of the anterior pineal.

13 Small area in the posterior pineal showing a well-developed intercellular network and associated masses of material staining dark blue with aldehyde fuchsin. Palex blue fibers and masses lie in a deeper plane in the section. Obliquely sectioned eapillaries appear at upper and lower left. Majority of nuclei are of parenchymal and neuroglial cells.

Figures 5,8 and 13 are from preparations stained with aldehyde fuchsin, orange $\mathrm{G}$, light green $\mathrm{SF}$, and chromotrope $2 \mathrm{R}$.

Figures 6, 7, 9-12 are from preparations stained with chrome alum hematox$y$ lin and phloxine. All $\times 2000$. 
VARIATION IN THE PINEAL,

PLATE 2

W. B. QUAY

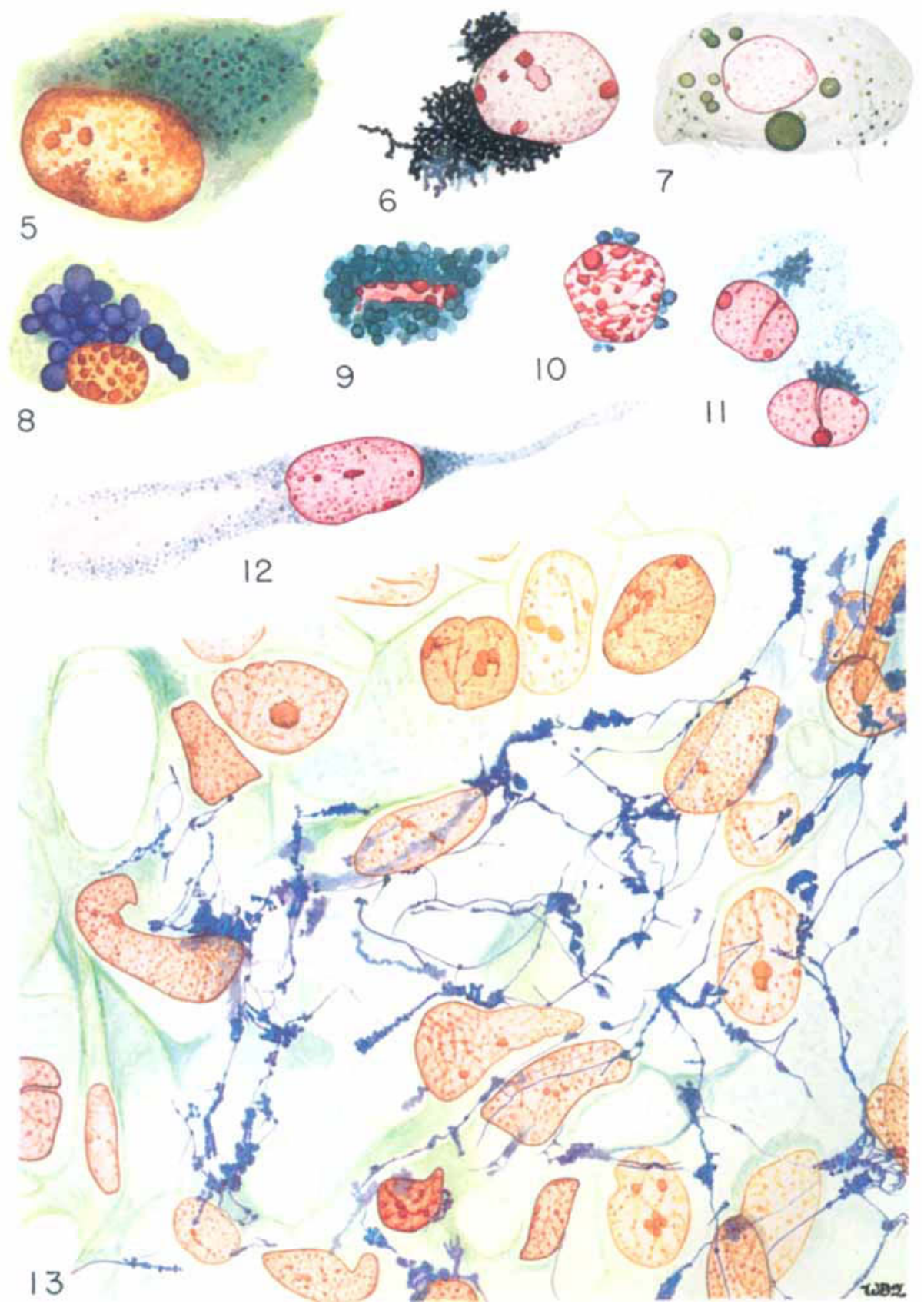

